\title{
Erişilebilir Turizm Açısından Safranbolu Turizm Destinasyonunun Uygunluğunun Değerlendirilmesi
}

\author{
Oğuz Dikera* ${ }^{*}$ Adnan Çetinkaya ${ }^{\mathrm{b}}$ \\ aKarabük Üniversitesi, Safranbolu Turizm Fakültesi, Karabük. \\ ${ }^{b}$ Karabük Üniversitesi, Safranbolu Meslek Yüksekokulu, Karabük.
}

\begin{abstract}
$\ddot{O} z$
Günümüzde engelli bireylerin sosyal hayata etkin bir șekilde katılmaları yönünde yapılan çalışmaların sayısı artmaktadır. Günümüzde sosyal bir faaliyet olan turizm hareketlerine engelli bireylerin de diğer bireyler gibi sorunsuz katılmalar yönünde yapılan çalışmalar önem kazanmıştır. Böylece turizmde erişilebilirlik kavramı gündeme gelmiştir. Erişilebilir turizm; temel insan olma hakkı sebebiyle engelleri olsa dahi bütün insanların, hareket etme, görme, işitme gibi imkânlarının tesis ve temini ile seyahat hareketlerine katılmalarını sağlayan turizm çeşididir. Erişilebilir turizm faaliyetlerinin düzenlenebilmesi için birçok uluslararası kuruluş tarafindan farklı yaklaşımlar ile düzenlenmesi zorunlu alt yapı şartları geliştirilmiştir. Literatürde en bilineni Birleşmiş Milletler Uluslararası Turizm Örgütü (WTO) tarafindan ortaya konulan şartlardır. Özellikle Avrupa'da yapılan çalışmalarda 7 şehir erişilebilir şehir olarak tanımlanmıştır. Ülkemiz turizm destinasyonları söz konusu şartlar açısından incelendiğinde bu şartlara kısmi uyumlu olduğu görülmektedir. Diğer yandan kimi destinasyonların erişilebilir turizm altyapısı açısından yetersiz olduğu ifade edilmektedir. Bu çalışma kapsamında popüler bir kültür turizmi destinasyonu olan Safranbolu erişilebilir turizm olanakları açısından değerlendirilmiş, uygun şartların să̆lanması ile ilgili öneriler sunulmuştur.
\end{abstract}

Anahtar Kelimeler: Engellilik, Erişilebilirlik, Erişilebilir Turizm, Safranbolu

\section{Evaluation of Safranbolu Tourism Destination in the context of Accessible Tourism}

\begin{abstract}
Today, the number of research on the effective integration of disable people to the social life has been increasing rapidly. Nowadays, the research on the attendance of disabled people to tourism movements come into prominence. Therefore, the term 'accessible tourism' become more important. Accessible tourism is a type of tourism which allows people to participate in tourism activities even if they have disabilities. There are many substructure criterias determined by different international organizations in order to provide accessible tourism activities The most well-known substructure criterias are provided by the UNWTO. In particular, under these substructure criterias, 7 European city have been determined as accessible cities. Turkish tourism destinations are somewhat compatible with these criterias. Besides some destinations have lack of substructure in terms of accessible tourism. In this paper, Safranbolu as a cultural tourism destination has been evaluated in terms of its accessible tourism potentials and some suggestions have been made for meeting the substructure criterias of accessible tourism.
\end{abstract}

Keywords: Disability, Accessibility, Accessible Tourism, Safranbolu 


\section{Giriş}

Hızla yaşlanan nüfusunun yanında dünyanın karşılaştığı bir diğer sorun engelli bireylerin sayısıdır. Birleşmiş Milletlerin verilerine göre dünya nüfusunun \%15'i engeller ile yaşamak zorundadır. Avrupa' da yaşayan 60 milyon kişi, Amerika' da ise 50 milyon civarında insan engellidir. Bu rakam ülkemiz için yaklaşık 1,5 milyon civarındadır. Söz konusu bireylerin sosyal yaşam başta olmak üzere hayatın her alanına koşulsuz olarak entegre edilmesi, engelli sayısının giderek artması sebebiyle çok önemlidir. Sosyal bir faaliyet olarak turizm faaliyetlerine engelli bireylerin katılmasının sağlanması da aynı derecede öneme sahiptir. Bu bağlamda engellilik kavramının açıklanması, engellilik türlerinin belirtilmesi, turizm faaliyetlerine katılmaları ile ilgili şartların belirlenerek turizm destinasyonlarının bu şartlara uygunluğunun araştırılması, uygun olmayan durumların tespiti ve çözüm önerilerinin tespiti ayrıca önem taşımaktadır. Bu bağlamda bu çalışmanın temel amacı, popüler kültür turizmi destinasyonlarından biri olan Safranbolu'nun engelli bireylerin turizm faaliyetlerine katılabilmeleri açısından uygunluğunun incelenmesi, uygun olmayan noktaların tespiti ile çözüm önerilerinin ortaya konulmasıdır.

\section{ENGELLİLIK KAVRAMI}

Engellilik kavramları anlayış ve algılayış açısından birçok farklı tanıma sahiptir. $\mathrm{Bu}$ tanımlar engel ve engelliliğe bakış açısı ya da ele alış biçimlerine göre farklılık göstermektedir. Engelliliği anlatmaya yönelik literatürde kullanılan en popüler tanımlardan birisi Dünya Sağlık Örgütü'nün (WHO) tanımıdır. Söz konusu tanım engelliliği üç olgu çerçevesinde açıklamakladır. Bu tanıma göre engellilik (WHO, 2011);

Noksanlık (Impairments): Vücut fonksiyonlarında problem ya da vücut yapısı içerisinde tahribat ile sonuçlanan durumları ifade etmektedir.

Hareket Sınırlılığı (Activity Limitations): Günlük aktiviteleri gerçekleştirme konusunda sağlıklı bir insana nazaran fiziksel anlamda hareket kısıtlılığının bulunması durumlarını ifade etmektedir.

Katılım Kısıtlılığ1 (Participation Restrictions): Herhangi bir fiziksel, ruhsal, duyusal rahatsızlık ve / veya noksanlık neticesinde sosyo kültürel açıdan kişinin sosyal faaliyetlere katılımının engellenmesi durumlarını ifade eder.

Engellilik ile alakalı bir başka tanım Birleşmiş Milletler tarafından 2000-2006 yılları arasında hazırlanmış ve Mart 2007'de imzaya açılan Engellilerin İnsan Haklarına Dair Sözleşme (United Nations Convention on the Rights of People with DisabilitiesCRPD) kapsamında yapılmıştır. Bu sözleşmede engelli kavramı; diğer bireylerle eşit koşullar altında topluma tam ve etkin bir şekilde katılımlarının önünde engel teşkil eden uzun süreli fiziksel, zihinsel, düşünsel ya da algısal bozukluğu bulunan kişileri içermektedir (UN CRPD, 2007).

Ülkemizde engellilik ile ilgili en resmi tanım 1/7/2005 tarih ve 5378 sayılı Engelliler Hakkında Kanun kapsamında yapılmaktadır. Söz konusu kanuna göre "engelli; fiziksel, zihinsel, ruhsal ve duyusal yetilerinde çeşitli düzeyde kayıplarından dolayı topluma diğer bireyler ile birlikte eşit koşullarda tam ve etkin katılımını 
kısıtlayan durum ve çevre koşullarından etkilenen bireyler" olarak tanımlanmaktadır (E.H.K, 2005).

Görüldüğü üzere engel ve engellilik kavramları birçok farklı içeriklerle ifade edilmektedir. Engellilik, genel kanının aksine, yalnızca bedensel ve duyusal kayıplar için değil aynı zamanda zihinsel, ruhsal kayıplar için de kullanılan bir kavramdır. Bu bağlamda farklı nedenlere bağlı olarak oluşan engellilik temel olarak beş başlıkta incelenmektedir (Koca, 2010);

- Zihinsel engelli

- Görme engelli

- İşitme ve Konuşma engelli

- Ortopedik engelli

- Süreğen Engelliler

Dünya Sağlık Örgütü (WHO) verilerine göre 2011 yılı dünya nüfusunun \%15’i fiziksel, zihinsel ya da duyusal engellere sahiptir (WTO, 2013). TUIKK verilerine göre Ulusal Özürlüler Veri Tabanına kayıtlı özürlülerin \% 29,2'si zihinsel özürlü, \% 25,6'sı süreğen hastalığı olan engelli, \% 8,8'i ortopedik engelli, \% 8,4'ü görme engelli, \% 5,9'u işitme engelli, \% 3,9'u ruhsal ve duygusal engelli, \% 0,2'si dil ve konuşma engelli ve \% 18'i birden fazla engele sahip kişilerdir. Kayıtlı engellilerin, \% 58,6'sı erkek, \% 41,4'ü kadındır (TUİ, 2010).

$\mathrm{Bu}$ durum gerek ülkemizde gerekse dünyada engelli kişi sayısının hiçte azımsanmayacak rakamlara ulaştığını göstermektedir. Söz konusu engelli nüfusunun yanı sıra yaşlılık nedeniyle kimi fiziki engelleri bulunan bireylerin de dahil olmasıyla rakamlar daha da artmaktadır. Bu açıdan sosyal yaşama katılımın bütün bireylerin olduğu gibi engelli bireylerin de en temel hakkı olması sebebiyle engelli bireylerin önemsenmesi ve bütün olanakların engellilerin özgürce katılımına uygun olarak düzenlenmesi gerekmektedir.

İlgili düzenlemelerin engellilerin seyahat ve turizm hareketlerine katılımları noktasında da gerçekleştirilerek söz konusu hareketlerin bütün bireylerin erişebilirliğine açılması gerekmektedir. Bu noktadan hareketle engelli bireylerin turizm hareketlerine katılımını ifade eden erişilebilir turizm kavramı önem kazanmaktadır.

\section{ERIŞIILEBILİR TURIZM OLGUSU}

Ülke ve bölgelerdeki engelli turist sayısı ve profili birçok araştırmacı ve örgüt tarafından farklı ifade etmektedir. Toerisme ve Vlaanderen (2001), Avrupa Birliği ülkelerinde toplam 35 milyon hareket engeli olan birey bulunduğunu belirtmektedirler. Yazarlar ayrıca 1 milyon işitme engelli, 80 milyon duyma sorunu olan ve 12 milyon görme sorunu olan bireyin varlığından söz etmektedirler. Phillips (2002), Birleşik Krallıkta engellilerin \%5'inin tekerlekli sandalye kullandığını belirtmektedir. Bu rakam yaklaşık 450,000 Britanyalının bedensel engele sahip olduğunu göstermektedir. Araştırmacı ayrıca Britanya'da 8.7 milyon duyma sorunu ve 
engeli olan, 1.8 görme engelli olan, 400.000 öğrenme engeli olan kişinin bulunduğunu vurgulamaktadır (Buhalis vd., 2005).

Avrupa'daki engelli sayılarına Amerika, Uzakdoğu, Avusturalya gibi ülkelerdeki engelliler de dahil edildiğinde dünya üzerindeki engelli nüfusunun 130 milyon kişiye ulaştığ 1 tahmin edilmektedir. Araştırmalar bu nüfusun yaklaşık \% 70'inin seyahat ettiğini göstermektedir. Bu kişilerin genellikle bir ya da birkaç kişinin refakatiyle seyahat ettikleri düşünüldügünde Avrupa'da seyahat eden potansiyel rakamın 130 milyon kişi olduğu ve bunların turizm harcamasının yaklaşık 80 milyar Avro'dan fazla olduğu, ABD'deki engelli nüfusunun ise 50 milyona yaklaştığı ve bu kesimin alım gücünün 175 milyar dolara ulaştığı görülmektedir (tursab.org, 2015 ).

Engelli bireylerin turizm ve seyahat faaliyetlerine katılımının artırılması, bu faaliyetlere katılımda yaşayacakları sorunların minimize edilmesi için yapılan çalışmalar Birleşmiş Milletler Dünya Turizm Örgütü'nün 1991 yılında Buenos Aires'te gerçekleştirdiği toplantı sonuç bildirgesi ile (Creating Tourism Opportunities for Handicapped People in the Nineties) hız kazanmış ve günümüze kadar ulaşmıştır.

Engellilerin turizm faaliyetlerine katılmalarını sağlamak amacıyla yapılan çalışmalarda, söz konusu turizm türü farklı araştırmacılar tarafından farklı kavramlarla ifade edilmiştir. Bunun nedeni, her araştırmacının bu turizm türünü ve bu turizme katılanların ihtiyaçlarını farklı şekillerde ele almalarıdır (Buhalis ve Darcy, 2010).

Tablo 1. Engelli Odaklı Turizm ile İlgili Tanımlar ve Çalışmalar

\begin{tabular}{|c|c|c|}
\hline $\begin{array}{c}\text { Engelli Turizmi (Disabled/ Disability } \\
\text { Tourism) }\end{array}$ & 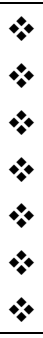 & $\begin{array}{l}\text { Buhalis, } 2005 \\
\text { Burnett ve Bender-Baker, } 2001 \\
\text { Daniels vd., } 2005 \\
\text { Darcy, } 2002 \\
\text { O'Neill ve Ali Knight, } 2000 \\
\text { Shaw ve Coles, } 2004 \\
\text { Yau vd., } 2004\end{array}$ \\
\hline $\begin{array}{c}\text { Kolay Erişim Turizmi (Easy Access } \\
\text { Tourism) }\end{array}$ & 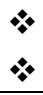 & $\begin{array}{l}\text { Cameron, } 2000 \\
\text { Tourism New South Wales, } 2005\end{array}$ \\
\hline Engelsiz Turizm (Barrier-Free Tourism) & $\%$ & $\begin{array}{l}\text { Cameron vd., } 2003 \\
\text { ESCAP, } 2000 \\
\text { Foggin vd., } 2003 \\
\text { Vignuda, } 2001 \\
\end{array}$ \\
\hline Kapsayıcı Turizm (Inclusive Tourism) & $\$$ & $\begin{array}{l}\text { Buhalis vd., } 2005 \\
\text { Shaw, } 2007 \\
\text { Yates, } 2007\end{array}$ \\
\hline Erişilebilir Turizm (Accessible Tourism) & 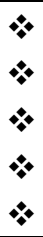 & $\begin{array}{l}\text { Buhalis vd., } 2006 \\
\text { Darcy vd. } 2008 \\
\text { Darcy ve Dickson, } 2009 \\
\text { Shaw, } 2007 \\
\text { Wu ve Cheng, } 2008\end{array}$ \\
\hline
\end{tabular}

Kaynak: Buhalis ve Darcy, 2010’dan uyarlanmıştır. 
İnsanlar farklı güdülerle çeşitli deneyimler elde etmek için seyahat etmektedirler. $\mathrm{Bu}$ nedenle engelli insanın da birbirinden farklı ihtiyaçları bulunmaktadır. Bu açıdan incelendiğinde engelli turizmi kavramı bu çeşitliliğin ortaya konmasını engellemektedir. Dolayısıyla günümüzde engelli turizmi kavramı "erişilebilir turizm (accessible tourism)" olarak evrimleşmiştir (Ayyıldız, Atay ve Yazıc1, 2014).

Erişilebilirlik ile ifade edilmek istenen, insan olmak ile bireylerin doğuştan elde ettikleri haklarından özgürce faydalanabilmeleri için bireylerin önünde hiçbir engel olmaksızın sürdürülebilir şekilde tüm hak ve hizmetleri edinmesinin ya da erişebilmesinin sağlanmasından dolayı söz konusu turizm türü erişilebilir turizm olarak adlandırılmaktadır (Darcy, Cameron ve Parker, 2008; Darcy ve Dickson, 2009; Wu ve Cheng, 2008).

Tüm bu ifadeler 1şı̆̆ında erişilebilir turizm; hareket etme, işitme, görme, zihinsel kısıtlılık gibi engelleri olan bireylerin evrensel olarak tasarlanmış turizm hizmetlerinden, mallardan ve turizm imkânlarından, bağımsız şekilde, etik ve eşitlik çerçevesinde yararlanabilmeleri ve kullanabilmeleri olarak tanımlanmaktadır (Darcy, Cameron ve Pegg, 2010).

Başka bir tanımla erişilebilir turizm; temel insan olma hakkı sebebiyle engelleri olsa dahi bütün insanların, hareket etme, görme, işitme gibi imkânlarının tesis ve temini ile seyahat hareketlerine katılmalarını sağlayan bir turizm çeşididir (Luiza, 2010).

Günümüzde engelli bireyler de diğer bireylerin sahip olduğu seyahat imkânlarından yararlanmak için yoğun çaba göstermektedirler. Ancak engelliler karşılaştıkları birçok engel nedeniyle turizm faaliyetlerinden yeterince yararlanamamaktadırlar. Engellerin çeşidi ve boyutu turizm destinasyonunun özelliklerine ya da kişinin turizm faaliyetlerine erişilebilirliğine göre değişse de sonuçta birçoğu ortak sayılabilecek şartlardan kaynaklanmaktadır. Engelli bireylerin turizm faaliyetlerine katılmada yaşadıkları sorunların sınıflandırılası ile ilgili olarak literatürde görüş birliği bulunmaktadır. Söz konusu sorunlar içsel ve dışsal engeller olarak iki başlıkta incelenmektedir.

İçsel engeller; bireylerin turizm faaliyetlerine katılımından önce ortadan kaldırılması gereken engellerdir. Söz konusu engeller bireyin turizm faaliyetlerine katılma güdüsünü kazanması ile ilgilidir. Bu tip engelleri birey gerek kendi başına gerekse profesyonel yardımlar ile ortadan kaldırabilir (European Comission, 2004).

Engelli bireylerin turizm faaliyetlerine katılmaları ile ilgili kendi sorunlarının dışında sıklıkla karşılaşılan diğer engeller dışsal engeller olarak adlandırılmaktadır. Mihaela vd. (2011) dişsal engelleri şu şekilde özetlemektedirler;

"Dışsal faktörler engelli bireylerin turizm faaliyetlerine katılımlardan alacakları hazzı azaltan ya da kısttlayan velveya engelleyen destinasyona ait özelliklerdir. Bunlar; konaklama tesislerindeki, müze ve ören yerlerindeki fazla basamaklar, engellilere uygun olmayan tuvaletler gibi yapısal engeller; düzensiz 
yollar, ă̆aç kökleri, kaldırımlar gibi çevresel engeller; engellilerin kullanımına göre dizayn edilmemiş arabalar, otobüsler gibi imkânlar ile yapılan seyahat engelleri; engelli insanlarm beraberlerinde engellerini ortadan kaldırmaya yönelik kullandikları ekipmanların kimi ortamlarda kullanımın engelleyen yasal engeller; ikili ilişkilerde müze, ören yeri ya da konaklama tesisi çalışanlarının gösterdikleri tepki ya da ilgisizliğin doğurduğu olumsuz yaklaşımlar; işaret dili vb. yönden eksik tesis ve müzelerin eksikliği nedeniyle ortaya çıkan iletişim engelleri ve bu engeller çerçevesinde ortaya çıkan yanlış bilgilendirmelerin oluşturduğu engellerdir" (Mihaela; Andrea ve Viorel, 2011).

Görüldügü üzere engelli bireylerin turizm faaliyetlerine katılmaları gerek bireysel gerekse destinasyonlara ait özellikler nedenleriyle kolay olmayan eylemlerdir. Diğer yandan söz konusu durumların ortaya çıkması, engelli bireyler nezdinde öz yargıların oluşmasına ve uzun süreli olarak turizm hareketlerinden uzaklaşmasına neden olmaktadir.

Engelliler için yıllardır ihmal edilmiş olan yasal düzenlemelerin bir çok ülkede (özellikle de gelişmiş ülkelerde) hayata geçirilmesi ve bu yasal düzenlemelerin yavaş yavaş etkisini göstermeye başlamasıyla birlikte eskisine oranla çok daha mobil hale gelmiş, çeşitli ekonomik ve sosyal olanaklara kavuşan engelliler, daha fazla seyahat etmeye başlamışlardır (www.tursab.org).

Söz konusu kanun ve yasal düzenlemeler engelli bireylerin turizm faaliyetlerine katılımını sağlasa dahi daha önce belirtilen engellerin ortadan kaldırılması, özellikle turizm destinasyonundaki fiziki düzenlemelerin engelleri kaldırıcı ve erişilebilir şekilde dizayn edilmesini gerekmektedir. Bu bağlamda Birleşmiş Milletler Dünya Turizm Örgütü (WTO) erişilebilir turizm için hedef destinasyonlarda turistik alt yap1 unsurlarının belirli niteliklerde düzenlenmesini önermektedir. Bunlar şu şekilde siralanmaktadir (WTO, 2013);

i. Park Alanları: Araç park yerleri ve yolcu indirme/bindirme alanlarının konaklama tesislerinde, müze ve ören yerlerine en yakın yerlerde, engelli bireylerin kullanımı için özel olarak dizayn edilmesi ve işaretlerle bunun vurgulanması gerekmektedir.

ii. İletişim: Hedef destinasyonlarda işaret dilinin kullanılabilmesi, görme engellilere yönelik alfabeler ile hazırlanmış giriş kartları ya da evrakların olması ve bütün bu prosedürler konusunda eğitimli personelin bulunması gerekmektedir.

iii. İşaretlemeler: Engelli kişilerin kolaylıkla kullanabileceği şekilde dizayn edilmiş fonksiyonel levha uyarı işaretlerinin olması, yine yürüme yollarında görme engellilerin yollarını takip edebilmeleri için işaret yollarının konulması gerekmektedir.

iv. Yatay Hareketler: Koridor, yürüyüş yolları, ziyaret alanları gibi engellilerin engellerine göre kullanabilecekleri genişlikte yolların ya da koridorların bulunması gerekmektedir. 
v. Dikey Hareketler: Dikey yürüme mesafeleri olan yerlerde asansör kullanımının yaygınlaşması gerekmektedir. Eğer asansör kullanımı imkansız ise merdivenlerde engelli rampaları ya da destek çubuklarının bulunması gerekmektedir. Böylece yukarı aşağı ya da aşağı yukarı yer değişimlerinin turizm faaliyetlerine katılmada mecburi olduğu alanlarda engelli bireyler rahatlıkla hareket edebilecektir.

vi. Taşıma: Turizm destinasyonlarında engelli bireylerin rahatlıkla seyahat edebilmeleri için toplu taşıma araçlarının söz konusu bireylerin kullanımı açısından ergonomik olarak tasarlanması gerekmektedir. Bunun yanında konaklama tesisleri, müze ve ören yerlerinde engelli bireylerin kullanımına uygun araç park yerlerinin bulunması gerekmektedir.

vii. Konaklama: Konaklama tesislerinin fiziki yapısının engelli bireylerin kullanımına uygun olması gerekmektedir. Girişlerde tüm engel tipleri göz önüne alınarak ihtiyaçların karşılanmasına yönelik dizayn edilmelidir. Katlar arası hareketlerde engelli bireylerin kolaylıkla erişip kullanabileceği şekilde dizayn edilmiş asansörlerin bulunması gerekir. Koridorlarda odalara, asansöre ulaşımı kolaylaştıracak şekilde işaretlerin bulunması gerekmektedir.

viii. Yeme-İçme Hizmetleri: Belirli sayıda restoran ya da masanın engellilerin kullanımı için dizayn edilmesi, Braille alfabesi ile hazırlanmış menü kartlarının bulundurulmasi gerekmektedir.

ix. Gezi Alanları: Müzeler, ören yerleri gibi turistik alanlarda yatay ve dikey hareketliliği kolaylaştıracak asansör imkanları, görme engelliler için sesli rehberler, işitme engelliler için görsel rehberlerin bulunması gerekmektedir.

x. Genel Hizmetler: Ankesörlü telefonlar, danışma ofisleri, check-in masaları gibi hizmetler bütün engelli bireylerin ulaşabilecekleri şekilde dizayn edilmeli ve kullanımları sağlanmalıdır.

Bütün bunların yanı sıra söz konusu bütün faaliyetlerin yürütülmesinde uzman personele ihtiyaç duyulmaktadır. Turizm faaliyetlerinin yürütülmesinde görevli olan bütün personelin engelli bireyler ile iletişim ve hizmet konusunda eğitimli olması gerekmektedir.

Birleşmiş Milletler Dünya Turizm Örgütü'nün 2015 yılında yayınladığı listede belirtildiği üzere Avrupa kıtasında yukarıda sıralanan özelliklere sahip 7 şehir erişilebilir kültürel miras şehri olarak belirtilmiştir. Bunlar; İsviçre'deki; Lozan, Cenevre, Luzern, Bern, Basel ve Zürih ile Fransa'daki Bordo şehirleridir. Söz konusu şehirler katılımclara tüm engel tiplerinde bireylerin rahatlıkla seyahat etme ve turizm faaliyetlerine katılımlarını sağlayacak imkanları sunmaktadır (WTO, 2015).

Söz konusu imkânlar ülkemiz turizmi açısından da özellikle son yıllarda önemsenmeye başlamıştır. Bu konuda yapılan akademik çalışmaların yanı sıra gerek Kültür ve Turizm Bakanlığı gerekse TÜRSAB'ın girişimleri ile son dönemlerde ülkemiz turizm bölgeleri erişilebilirlik konusunda girişimlerde bulunmaktadır. Ancak söz konusu girişimler şu aşamada yetersiz gözükmektedir. 
Şen ve arkadaşları (2014) yaptıkları çalışmada Türkiye'de yer alan ve UNESCO koruması altında olan Kültür Varlıkları ve Müzelerin engelli turistlerin ziyaretine uygunluğunu araştırmışlardır. Araştırma kapsamında "Divriği Ulu Camii ve Darüşşifası, İstanbul'un Tarihi Alanları, Göreme Millî Parkı ve Kapadokya, Hattuşa, Nemrut Dağg, Hieropolis-Pamukkale, Xanthos-Letoon, Safranbolu Şehri, Truva Antik Kenti, Edirne Selimiye Camii ve Külliyesi, Çatalhöyük Neolitik Kenti, Bergama Çok Katmanlı Kültürel Peyzaj Alanı, Bursa ve Cumalıkızık: Osmanlı İmparatorluğu'nun Doğuşu" kültür varlıkları ve müzeler incelenmiştir. Araştırma sonucunda destinasyonlarda engellilere yönelik kısmi hizmetlerin verildiği belirlenmiştir (Şen, Yetim ve Bilici, 2014).

Tozlu ve arkadaşlarının (2012), Çanakkale turizm destinasyonun erişilebilir turizm konusundaki uygunluğunu tespit etmeye yönelik olarak yaptıkları çalışmada, Çanakkale'de bulunan çekim merkezlerinin, engelli bireyler açısından pek çok engelleyici ve kısıtlayıcı özelliği olduğunu tespit etmişlerdir. Araştırmada ziyaret merkezlerinde engellilere yönelik işaretlemelerin, engelli park alanlarının ve işitme engelliler için audio sisteminin bulunmadiğı, en önemli alanlardan olan engelli tuvaletlerinin de neredeyse hiç bulunmadığı belirlenmiştir (Tozlu, Mercan ve Atay, 2012).

Benzer bir çalışmada Yörük (2003), ülkemizde turizm faaliyetlerinde engelli bireylerin kullanımı ile alakalı alt yapı yetersizlikleri olduğunu vurgulanmaktadır. Yaylı ve Öztürk (2006), yaptıkları çalışmada ülkemizde engellilerin turizm faaliyetlerine katılımları ile ilgili bilgilendirme noktasında problemler olduğunu bunun yanında alt yapı sorunlarının da bulunduğunu ifade etmektedirler.

Çalışmalardan da açıkça görüldüğü üzere ülkemiz genelinde turizm hareketlerinin gerçekleşmesinde ve hareketlerin gerçekleştiği alanlarda gerek alt yapı gerekse bilgilendirme eksikleri nedeniyle erişilebilirlik açısından problemler olduğu gözlemlenmektedir.

\section{ERIŞİLEBİLİR TURIZM AÇISINDAN SAFRANBOLU DESTINASYONU}

Antik çağlarda yaşamın izine rastlanan Safranbolu ilçesinde sırası ile Hititler, Frigler, Persler, Helenistik krallıklar, Romalılar, Selçuklular, Çobanoğulları, Candaroğulları ve Osmanlı egemenliğinin izleri görülmektedir. Kentin en önemli çekiciliğini 18 ve 19. yy Osmanlı sivil mimarisinin en güzel örneklerinden olan Konaklar oluşturmaktadır.

1975 yılında Yüksek Anıtlar Kurulunun kentin bazı bölgelerini "Kentsel Sit” alanı ilan etmesiyle kentin önemi ortaya çıkmıştır. Bu durum turizm faaliyetlerinin 90'lı yılların başından itibaren gelişmesiyle büyük bir ivme kazanmıştır. 1994 yılında UNESCO tarafından “Dünya Miras Kenti” unvanı alması ile iyice hılanan turizm hareketleri günümüzde yıllık ortalama 750 bin ziyaretçi sayısıyla yoğun bir şekilde devam etmektedir.

Kültür turizmi bakımından zengin bir potansiyele sahip olan Safranbolu destinasyonu özellikle eski yerleşimin yoğun olduğu "Çarşı" mevkii ile öne çıkmaktadır. Eski Hükümet Binası, Saat Kulesi, Eski Cephane Binası, Eski Hapishane 
Binası, tarihi konaklar, İzzet Mehmet Paşa, Köprülü Mehmet Paşa, Kazdağlığlu, Dağdelen, Kaçak, Mescit Camiileri, Cinci Hanı ve Hamamı bu bölgede görülmeye değer tarihi yapılardır. İki anıt mezarın da bulunduğu Hıdırlık Tepesi, açık hava namazgahı olarak kullanılmış olup kentin seyir terasıdır.

Diğer yandan Osmanlı İmparatorluğunda ticaretin bel kemiği olan Lonca sisteminin emareleri Safranbolu’da hala görülmektedir. Bugün halen üretimin sürdüğü Demirciler, Bakırcılar, Kalaycılar ve Semerciler çarşıları ile Yemeniciler Arastası ve çevresindeki dükkânlar söz konusu kültürün öğelerinin görülmesi ve yaşanması açısından ziyaretçilere fırsatlar sunmaktadır.

Safranbolu turizm destinasyonu kültür turizminin yanı sıra alternatif turizm çeşitleri için de uygun alanlara sahiptir. İncekaya Su Kemeri, Cam Teras, Hacılarobası ve Üçbölük Köyleri çevresindeki kaya mezarları, Bulak Mağarası ile Hızar Mağarası, Yörük Köyü, kanyonlar, yaylalar turistler açısından diğer cazibe unsurlarıdır.

Karabük Kültür ve Turizm İl Müdürlüğü verilerine göre ${ }^{12} 2015$ yılı ilk 6 ayında Safranbolu turizm destinasyonundaki konaklama tesislerinde 115.060 geceleme yapılmıştır. Söz konusu gecelemelerin 23.829'u yabancı turistler tarafından 91.231'i ise yerli turistler tarafından gerçekleştirilmiştir. Bu rakamlardan da açıkça görülmektedir ki Safranbolu turizm destinasyonu gerek yerli gerekse yabancı turistler tarafindan rağbet görmektedir.

Turizm alt yapısı bakımından eksikleri olmasına karşın nitelikli bir altyapıya sahip olan kent, erişilebilir turizm açısından değerlendirildiğinde yeterli donanına sahip değildir.

Şen ve arkadaşları (2014)'nın Türkiye'de UNESCO koruması altında bulunan Kültür Varlıkları ve Müzelerin engelli turistlerin ziyaretine uygunluğunun değerlendirilmesi amacıyla yaptıkları çalışma turizm destinasyonlarında engellilere yönelik donanım ve hizmetleri ortaya koymaktadır (Bkz. Tablo.2).

${ }^{1}$ Yıllık bazda 2015 yılına ait turizm istatistikleri, çalışmanın hazırlandığı tarihte yayınlanmadığından ötürü ilk 6 ayı baz alınmıştır. 
Tablo 2. UNESCO Dünya Miras Alanlarında Engellilere Hizmet Verme

\begin{tabular}{|c|c|c|}
\hline Müze Adı & $\begin{array}{c}\text { Engellilere } \\
\text { Hizmet Verme } \\
\text { Durumu } \\
\end{array}$ & $\begin{array}{c}\text { Verilen Hizmetin Engel } \\
\text { Durumuna Göre Sıralanışı }\end{array}$ \\
\hline Xanthos-Letoon & Kismen & Fiziksel Engelli. \\
\hline $\begin{array}{l}\text { Göreme Milli Parkı ve } \\
\text { Kapadokya }\end{array}$ & Kismen & Fiziksel, Zihinsel Engelli. \\
\hline Nemrut Dağ1 & Evet & Fiziksel, Görme Engelli. \\
\hline Hattuşaş (Boğazköy) & Evet & Fiziksel Engelli. \\
\hline $\begin{array}{l}\text { Divriği Ulu Camii ve } \\
\text { Darrüşşifası }\end{array}$ & Evet & $\begin{array}{l}\text { Fiziksel, Duyma, Görme, } \\
\text { Zihinsel Engelli. }\end{array}$ \\
\hline $\begin{array}{l}\text { Selimiye Camii ve } \\
\text { Külliyesi }\end{array}$ & Hayır & $\begin{array}{l}\text { Fiziksel, Zihinsel, Görme, } \\
\text { Duyma Engelli. }\end{array}$ \\
\hline $\begin{array}{l}\text { İstanbul'un Tarihi } \\
\text { Alanları } \\
\text { Topkapı Ayasofya }\end{array}$ & Evet & $\begin{array}{l}\text { Fiziksel, Zihinsel, Görme, } \\
\text { Duyma Engelli. }\end{array}$ \\
\hline Bergama & Evet & $\begin{array}{l}\text { Fiziksel, Zihinsel, Görme, } \\
\text { Duyma Engelli. }\end{array}$ \\
\hline Truva Antik Kenti & Evet & $\begin{array}{l}\text { Fiziksel, Zihinsel, Görme, } \\
\text { Duyma Engelli. }\end{array}$ \\
\hline $\begin{array}{l}\text { Çatalhöyük Neolitik } \\
\text { Kenti }\end{array}$ & Evet & $\begin{array}{l}\text { Fiziksel, Zihinsel, Görme, } \\
\text { Duyma Engelli. }\end{array}$ \\
\hline Bursa & Evet & $\begin{array}{l}\text { Fiziksel, Zihinsel, Görme, } \\
\text { Duyma Engelli. }\end{array}$ \\
\hline Pamukkale-Hierapolis & Evet & $\begin{array}{l}\text { Fiziksel, Zihinsel, Görme, } \\
\text { Duyma Engelli. }\end{array}$ \\
\hline Safranbolu & Hayır & - \\
\hline
\end{tabular}

Kaynak: Şen, Yetim ve Bilici, 2014

Tabloda görüldüğü üzere UNESCO “Dünya Miras Listesinde” bulunan diğer emsallerinin aksine Safranbolu destinasyonu müze ve ören yerlerinde engellilere hizmet verilmemektedir. Birleşmiş Milletler Dünya Turizm Örgütü'nün belirlediği kriterler dikkate alındığında Safranbolu destinasyonun erişilebilir turizm açısından değerlendirmesi aşağıdaki şekilde yapılabilir;

Park Alanları: Safranbolu turizm bölgesindeki otoparklar engelli misafirlerin araçlara iniş ve binişleri için uygun özelliklere sahip değildir. Park alanları genellikle turistik çekiciliği olan yerlere uzaktır ve trafiğin yoğun olduğu bölgelerdedir. Bu engelli misafirlerin gerek toplu taşıma gerekse bireysel olarak park alanlarını kullanmalarında sorunlar yaratmaktadır.

İletişim: Turizm enformasyon bürosunda işaret dilini kullanabilen uzman personel olmadığı gibi konaklama tesisleri ve diğer alanlarda engelli bireyler ile iletişim konusunda danışmanlık ya da tercümanlık yapabilecek personel bulunmamaktadır. 
İşaretlemeler: Safranbolu'da gerek yürüyüş yollarında gerekse müze içlerinde görme engellilerin, yürüme engellilerin ya da işitme engellilerin seyahatlerini kolaylaştıracak şekillerde işaretlemeler ve levhalar bulunmamaktadır.

Yatay Hareketler: Safranbolu şehrinde kültürel öğelerin yoğunlukla bulunduğu "Çarşı" kesiminde sokaklar tekerlekli sandalyelerin hareketini engelleyen "parke taş" ile kaplıdır. Benzer şekilde görme engellilerin de bu sokaklarda yürümesi imkansızdır. Müze, konak ve konaklama tesislerindeki koridorlar da genellikle yatay hareketleri kısıtlamaktadır. Keza Yörük Köyü fiziksel yapı bakımından "Çarşı" mevkii ile benzerlik taşımakta ve engelli bireylerin gezilerini sınırlamaktadır.

Dikey Hareketler: Şehirde bulunan müzelerde dikey hareketlerin sağlanması (asansör, yürüyen merdiven v.b.) için alt yapı bulunmamaktadır. Benzer şekilde, tarihi konaklarda da engellilerin dikey hareketlerini sağlayacak imkan bulunmamaktadır.

Önemli turistik mağaralardan biri olan Bulak Mencilis mağarasında yürüme ve görme engelli misafirlerin ulaşımları için alt yapı bulunmamaktadır. Benzer biçimde İncekaya Su Kemeri ve İncekaya Kanyonu'nda dikey hareketler açısından alt yapı bulunmamaktadır. Eski şehrin en iyi şekilde gözlemlenebildiği Hıdırlık Tepesi içerisinde engellilerin kullanımına yönelik alanlar ve dikey-yatay hareket imkanları sinırlidır.

Taşıma: Safranbolu turizm destinasyonunda engelli bireylerin toplu taşıma araçları ile seyahat imkanları kısıtlıdır. Turistik cazibelerin yoğun olduğu bölgelere toplu taşıma seferleri, belediye ve kooperatif araçları ile yapılmaktadır. Kooperatif araçlarında engelli bireylerin seyahat imkanları kullanılan araçların özellikleri nedeniyle mümkün değilken, belediye araçları ile erişim ise sınırlıdır. Bunun yanında söz konusu araçlara inmek ve binmek için kullanılan duraklar ise engelli bireylerin kullanımı için uygun değildir.

Konaklama: Karabük Kültür ve Turizm İl Müdürlüğü verilerine göre 2015 yılında Safranbolu ilçesinde belediye belgeli ve işletme belgeli olmak üzere toplam 101 adet konaklama tesisi bulunmaktadır (Bkz. Tablo 3 ). Söz konusu tesislerden yalnızca 7 'sinde engelliler için alt yapı imkanı mevcut olup bu alt yapı yalnızca yürüme engelli misafirlerin kullanımına uygun olarak dizayn edilmiştir.

Tablo 3. 2015 Yılı İtibariyle Safranbolu'daki Konaklama Tesisleri Sayısı

\begin{tabular}{|l|c|c|}
\hline \multicolumn{1}{|c|}{ Tesisin Belge Türüne Göre } & $\begin{array}{c}\text { Tesis } \\
\text { Sayısı }\end{array}$ & $\begin{array}{c}\text { Yatak } \\
\text { Kapasitesi }\end{array}$ \\
\hline Turizm İşletme Belgeli Tesis & 21 & 1022 \\
\hline Belediye Belgeli Tesis & 80 & 1849 \\
\hline TOPLAM & $\mathbf{1 0 1}$ & $\mathbf{2 8 7 1}$ \\
\hline
\end{tabular}

Kaynak: Karabük İl Kültür ve Turizm Müdürlüğü, 2015

Yeme-İçme Hizmetleri: Doğrudan engellilerin kullanımı için tasarlanmasa da orta ve büyük ölçekli tesislerde kısmen engelli bireylerin rahat kullanabileceği imkanlar bulunmaktadir. 
Gezi Alanları: Gezi alanlarında yürüme engellilerin rahat hareket edebilecekleri alanlar kısıtlıdır. Diğer yandan görme engelli bireylerin kullanımına yönelik yaygın bir sesli rehber kullanımı yoktur. İşitme engelli bireylerin rahatlıkla algılayabilecekleri görsel rehberler bulunmamaktadır. Bunların yanı sıra söz konusu gezi alanlarına engelli misafirleri yönlendirme noktasında uyarı ya da ikaz sistemleri de bulunmamaktadir.

Genel Hizmetler: Safranbolu turizm destinasyonunda turizm enformasyon ofisi engelli bireylerin erişim ve kullanımına uygun olarak dizayn edilmemiştir. Diğger yandan bölgede engellilerin kullanımına uygun tuvalet yok denecek kadar azdır. Yine engelli bireylerin kullanabilecekleri ATM, ankesörlü telefon vb. imkanlar bulunmamaktadır. Daha önce de belirtildiği gibi otobüs durakları gerek işaretlemeler gerekse fonksiyonellik açılarından engelli bireylerin kullanımına uygun değildir.

Bu bilgiler 1şı̆̆ında açıkça görülmektedir ki Safranbolu turizm destinasyonu erişilebilir turizm imkanları ve alt yapısı açısından uygun değildir. Bu bağlamda destinasyondaki alt yapının en azından asgari düzeyde erişilebilir turizm için uygun hale getirilmesi hem toplumsal sorumluluk açısından hem de potansiyel pazarın genişletilmesi açısından önem taşımaktadır.

\section{SONUÇ VE ÖNERILER}

Engel ve engellilik olgusu fiziksel bir olgu olduğu kadar sosyal ve psikolojik bir durumdur. Genel kanının aksine bireyler yalnızca fiziksel, görme ve işitme olarak değil bunun yanında psikolojik ile süreğen engeller olarak farklı tip ve çeşitlerde engele sahip olabilmektedir.

Engelli bireylerin hak ve hürriyetleri ve sosyal yaşamlarının düzenlenmesi ile alakalı birçok yasa, yönetmelik ve uluslararası farklı kuruluşlar (WHO, EU gibi) tarafından hazırlanmış çalışmalar bulunmaktadır. Söz konusu çalışmaların odak noktası, engelli bireylerin de diğer tüm bireylerin sahip olduğu hak ve hürriyetlere sahip olabilmeleri, engellerine bakmaksızın istedikleri faaliyetlerde bulunabilmeleri için imkan sağlanmasıdır.

İlgili yazın incelendiğinde engelli bireylerin sahip oldukları hak ve hürriyetleri kullanmakta sorunlar yaşadıkları en temel faaliyetlerden birisi turizm ve seyahat faaliyetleridir. Turizm faaliyetleri, içerik gereği ağırlıklı olarak engeli olmayan insanlara göre dizayn edilmekte ve yürütülmektedir. Fakat söz konusu faaliyetlere katılmak engelsiz bireylerin olduğu kadar engelli bireylerin de hakkıdır. Bu bağlamda turizm faaliyetlerinin bütün bireylerin ihtiyaçlarını karşılayacak şekilde düzenlenmesi ile ilgili adımlar atılmaya başlanmıştır. Böylece zaman içerisinde farklı kavramlar ile açıklansa da günümüzde "erişilebilir turizm" olarak adlandırılan turizm çeşidi gündeme gelmiştir.

Birleşmiş Milletler Dünya Turizm Örgütü (UNWTO) erişilebilir turizm alt yapısının turizm destinasyonlarında uygulanabilmesi için ihtiyaç duyulan alan ve hizmetleri sınıflandırmıştır. Söz konusu alan ve hizmetler; park alanları, iletişim, işaretlemeler, yatay hareketler, dikey hareketler, taşıma, konaklama, yeme-içme 
hizmetleri, gezi alanları, genel hizmetler şeklinde sıralanmaktadır. UNWTO tarafından Avrupa'da toplam 7 şehir " erişilebilir" turizm şehirleri olarak belirlenmiştir.

Ülkemiz turizm destinasyonları üzerine yapılan birçok araştırmada (örn: Yörük, 2003, Tozlu ve arkadaşları, 2012) ülkemizin erişilebilir turizm imkanları ve alt yapısı açısından zayıf hatta yer yer olanaksız olduğu ifade etmektedirler. Ülkemizdeki Dünya Miras Kentleri' üzerinde yapılan çalışmalar ülkemizde erişilebilir turizm olanaklarının sınırlı olduğunu göstermektedir. Şen ve arkadaşları (2014) yaptıkları çalışmada 13 müze ve ören yerinden 10'unun engelliler için erişilebilir olduğu, 2'sinin ise kısmen erişilebilir olduğu sonucuna ulaşmışlardır. Dünya Miras Kentlerinden yalnızca Safranbolu erişilebilir turizm faaliyetlerine uygun değildir.

UNWTO'nın erişilebilir turizm alt yapı kriterleri bakımından incelendiğinde Safranbolu'da birçok eksik göze çarpmaktadır. Bu eksikliklerin belediye, valilik ya da yerel turizm kuruluşları tarafından geliştirilecek projeler ve çalışmalar sayesinde giderilmesi halinde destinasyon erişilebilir turizm faaliyetlerinin yürütülmesi için uygun hale gelecektir. Söz konusu eksikler ile ilgili çözüm önerileri şu şekilde siralanabilir;

Safranbolu'daki otoparklar engelli misafirlerin araçlarına kolay biçimde iniş ve binişlerini sağlayacak şekilde uygun özelliklerde yeniden dizayn edilmelidir. İniş ve binişler esnasında engelli bireylerin kaza riski yaşamayacağı şekilde güvenlikli alanlar oluşturulmalıdır. Engelli bireylere ayrılan otopark sayısı arttırılmalı, söz konusu alanların başkaları tarafından kullanımı engellenmelidir.

Diğer yandan turizm faaliyetlerinin yoğun olarak yürütüldüğü alanlara gidişte ve alanların içerisinde, levha ile işaretlemelere özen gösterilmelidir. Özellikle görme engelli bireylere göre dizayn edilecek işaretli yürüyüş yolları ile işitme engelliler için hazırlanacak görsel işaretler vasıtasıyla söz konusu sorunlar giderilmelidir. Bu işaretlemeler özellikle yoğunluğun bulunduğu "Çarşı" mevkiinde sistematik olarak yapılmalıdır. Buna ilave olarak Safranbolu turizm danışma bürosunda işitme engelli bireyler ile anlaşabilecek çalışanlar ya da bu ihtiyacı karşılayacak teknolojik sistemin hazır bulundurulması gerekmektedir.

Bir başka düzenlemesi gereken unsur da, engelli misafirlerin yatay ve dikey hareketliliğidir. Çarşı bölgesi başta olmak üzere şehirdeki diğer bütün turizm alanlarında öncelikli olarak yollar, fiziki engellilerin tekerlekli sandalye ile hareketini kolaylaştıracak şekilde düzenlenmelidir. İkinci olarak yollara görme engelli misafirlerin yönlerini bulabilecekleri şekilde engelli yolları düzenlenmesi gerekmektedir. Eğer söz konusu düzenlemeler bütün sokaklar için gerçekleştirilemeyecek ise turizm alanlarında engelli misafirlerin ziyaretine imkân tanıacak parkurların hazırlanması gerekmektedir. Bu düzenlemeler konaklama tesisi olarak konakların çevreleri ve binalarında da uygulanmalıdır.

Engelli bireylerin yalnızca yatay hareketleri değil dikey hareketlerine de imkan tanınmalıdır. Engelli bireylerin müzeye çıkışlarında ya da müze içinde kullanabilmeleri için antlar kurulunun izin verdiği ölçüde bir asansör ya da benzeri 
bir araç inşa edilmelidir. Yine asansör zorunluluğu İncekaya Kanyonu ve Su Kemeri bölgesi ile Bulak Mağarası için de bir zorunluluktur. Özelikle kanyon bölgesine iniş ve Bulak Mağarasına çıkış engelli bireyler için oldukça zor görünmektedir.

Turizm hareketlerinin yoğun olduğu bölgelere yapılan toplu taşımacılıkta kullanılmak üzere engellilerin de yararlanabileceği engelli indirme bindirme mekanizması olan otobüsler satın alınmalıdır.

Safranbolu turizm destinasyonu konaklama açısından da engelli bireylere fazla imkânlar sunamamaktadır. Bölgede faaliyet gösteren 101 konaklama tesisinin sadece 7'si engelli bireylere uygun hizmetler sunmaktadır. Söz konusu hizmetler genelde fiziksel engelliler içindir. Bu durumun ortadan kalkması için öncelikli olarak engellilere hizmet veren konaklama tesisi sayısını arttırmak, hatta diğer engelli bireylerin kullanımına göre de yeniden düzenlemek gerekmektedir. Benzer şekilde yiyecek-içecek tesislerinin de engelli bireyler için yeniden düzenlenmesi gerekmektedir.

Son olarak yerel hizmetler ile ilgili olarak da Safranbolu şehrinin bütün turizm alanlarında revizyona gidilmesi gerekmektedir. Engelli bireyler için tuvalet sayılarının arttırılması, ankesörlü telefon gibi iletişim olanakları ile ulaşım imkanlarının engelli bireylerin kullanabileceği formatlara dönüştürülmesi gerekmektedir. Ayrıca bütün gezi alanları ile tesislerde sesli rehberlerin bulunması, işaretlemelerin etkin bir şekilde kullanılması ve Braille alfabesi ile uyarıların hazırlanması gerekmektedir.

Yukarıda özetlenen eksiklerin giderilmesi halinde Safranbolu destinasyonu asgari düzeyde erişilebilir olacaktır. Bu konuda yapılacak bilimsel çalışmalar bu eksikliklerin ortaya konmasında ve çözüm üretilmesinde yarar sağlayacaktır.

\section{KAYNAKÇA}

Ayyıldız, T., Atay, H., Yazıcı, A. (2014). Konaklama İşletmelerinin Engelliler için Olanakları ve Yöneticilerin Görüşleri: Kuşadası Örneği, Gazi Üniversitesi Turizm Fakültesi Dergisi 2 (2014), 84-100.

Buhalis, D., Darcy, S. (2010). Accessible Tourism: Concepts and Issues, Channel View Publications, Canada.

Buhalis, D., Eichhorn, V., Michopoulou, E., Miller, G. (2005). Accessibility Market and Stakeholder Analysis, OSSATE/ University of Surrey, UK, 1-88.

Caldwell, L.L., \& Gilbert, A.G. (1990). Leisure, health and disability: A review and discussion. Canadian Journal of Community Mental Health, 9(2), 111-122.

Darcy, S. And Dickson, T. (2009) A whole-of-life approach to tourism: The case for accessible tourism experiences. Journal of Hospitatlity and Tourism Management 16 (1), 32-44.

Darcy, S. Cameron B. Pegg S. Packer, T. (2008) Technical Report 900042: Developing Business Cases for Accessible Tourism, STCRC technical report.

Darcy, S. Cameron B. Pegg S. Packer, T. (2010). Accessible Tourism and Sustainability: A Discussion and Case Study, Journal of Sustainable Tourism, 18:4, 515-537.

Engelliler hakkında kanun. (2005). T.C. Resmi Gazete, 5378, 1 Temmuz 2005. 
European Commision (2004). Improving Information on Accessible Tourism for Disabled People, EU, Italy.

Koca, C. (2010), “Engelsiz Şehir Planlaması Bilgilendirme Raporu”, Dünya Engelliler Vakfı, İstanbul.

Luiza, M., S. (2010). Accessible Tourism- The Ignored Opportunity, Romania Economic and Business Review, 7, 1154-1157.

Mihaela, B. C., Andrea, N., Viorel, F. A. (2011). The Tourism Barriers Of The Disabled In Romania, Annals of the University of Oradea, Economic Science Series, 201-205.

Şen, N., Yetim, Ç. A., Bilici, N. (2014). Kültür Varlıkları ve Müzelerin Engelli Turist Ziyaretine Uygunluğunu Belirlemeye Yönelik Bir Araştırma, Erzincan Üniversitesi Sosyal Bilimler Enstitüsü Dergisi, VII-I: 1-16.

Tozlu, E., Mercan, O. Ş., Atay, L. (2012). Çanakkale'nin Engelli Turizmine İlişkin Durumunun Belirlenmesine ve Planlanmasına Yönelik Bir Çalışma, Aksaray Üniversitesi, Cilt:4, Sayı: 1.

Türkiye İstatistik Kurumu (2010). Özürlülerin Sorun Ve Beklentileri Araştırması, Ankara.

United Nations (2007). United Nations Convention on the Rights of People with Disabilities, Paris, France.

World Health Organization (2011). World Report On Disability, The World Bank, Malta.

World Tourism Organization (1991). Accesible Tourism for All, UNWTO, Buenos Aires.

World Tourism Organization (2013). Recommendations on Accesible Tourism, UNWTO, Madrid.

World Tourism Organization and Fundación ACS (2015), Manual on Accessible Tourism for All - Public-Private Partnerships and Good Practices, UNWTO, Madrid.

$\mathrm{Wu}, \mathrm{Y}$. And Cheng, M. (2008) Accessible Tourism for disabled: Long tail theory. Emerging Technologies and Information Systems for the Knowledge Society, Heidelberg, Springer.

www.tursab.org.tr

Yaylı, A., Öztürk, Y. (2006). Konaklama İşletmeleri Yöneticilerinin Bedensel Engelliler Pazarına Bakış Açıları Üzerine Bir Araştırma, Anatolia: Turizm Araştırmaları Dergisi, C: 17, S: 1, Bahar: 87-97.

Yörük, Ü. K. (2003). Turizm Yapılarının Tasarımında Özürlü Etmeninin İrdelenmesi, Yıldız Teknik Üniversitesi Fen Bilimleri Enstitüsü, Yayınlanmamış Yüksek Lisans Tezi. 